\title{
A Case Report on Lumbar Stenosis Secondary Intervertebral Disc Prolapse on to IVDP L4/L5 Associated with Hypertension and Hypothyroidism in Female
}

\author{
Arumugam MuthuKumar*, Rajaram Gayathri, Deepam Pradhan, Pelden Dema, Rumana Khatija, Mohan Sellappan \\ Department of Pharmacology, Krupanidhi College of Pharmacy, Bangalore, Karnataka, INDIA. \\ Department of Pharmaceutics, Karpagam College of Pharmacy, Coimbatore, Tamil Nadu, INDIA.
}

\begin{abstract}
The chief clinical indication of Spinal Stenosis is persistent pain, severe stenosis, weakness and even including regional anesthesia in patients. One of the major impediments of critical Lumbar spinal stenosis (LSS) is Central cord syndrome which indeed is a cervical spinal cord injury. It may further extend the injury and also resulting in the osteoarthritic spine. Patients with LSS become typical with pain, nervous disorder, formication or neurologic negotiation causing discomfort. As per few studies and natural history around 146 patients with LSS were not suggested for surgical method. This was mainly due to adequate symptom levels. This condition is prevalent in people (40-60years). Whereas, it is seen very commonly in case of geriatric patients (usually above the age of 60). This is a case of a 63-yearold female known hypertensive, hypothyroidism with complaints of paresis because of severe lumbar spinal stenosis. Based on the patient's complaint and disease state the patient was advised to undergo related tests and procedures for further specification of the treatment. In the world, today
\end{abstract}

about 1 per 1000 persons older than 65 years and about 5 of every 1000 persons older than 50 years are seen to acquire such condition like lumbar spinal stenosis. Therefore $60-85 \%$ of patients having such condition are known to have fulfilling improvements due to surgical treatments.

Key words: Lumbar Spinal Stenosis, Paresis, Spondylosis, Osteoarthritis, Degenerative disc disease, Central cord syndrome, Formication.

Correspondence

Dr. Arumugam MuthuKumar

Department of Pharmacology, Krupanidhi College of Pharmacy, Bangalore-560035, Karnataka, INDIA.

Phone: +919976696000

Email: mkpharmacologist@gmail.com

DOI: $10.5530 /$ jyp.2020.12.78

\section{INTRODUCTION}

Lumbar spinal stenosis (LSS) is a medical condition that is known to narrow as well as compress the nerves along with blood vessels, especially at the lumbar vertebrae. ${ }^{1,2}$ Apart from causes like degenerative arthritis or degenerative disc disease, LSS can also be developed by trauma, tumor or various dysplasia's (abnormal development of cells within tissues/ organs). It can be even caused by a condition that reduces the spinal canal or vertebral foramen. It can affect the thoracic region that leads to the development of thoracic spinal stenosis. ${ }^{3-5}$ Few major side effects caused due to LSS are numbness in feet, legs, thighs, or buttocks. Some of the symptoms characterized by LSS include pseudo-claudicating (impingement or sensation of inflammation from the spinal cord along with inducing leg pain due to walking or prolonged standing). These above conditions are seen to be relieved with sitting, lying down and forward bending. ${ }^{6,7}$ The medical experts generally diagnose LSS based on the patient physical examination, medical history and even imaging. ${ }^{8}$ Despite all these, there is generally no precise standard diagnosis for LSS. Sometimes even the radiographic results show poor compatibility with patient symptoms. Therefore various electro-diagnostics and radiological test are carried out. Hence the health care centers need to provide an accurate diagnosis for better patient compliance. ${ }^{9-11}$

\section{CASE REPORT}

A 63-year-old female presented with signs of LSS was referred to a hospital in Bangalore. There was no history of any metabolic disorder or other diseases in the past until April 2019, she was taken to the hospital due to sudden symptoms like fatigue, shortness of breath, chest pain etc which was later confirmed to be caused by hypertension. The blood pressure observed initially was $130 / 90 \mathrm{mmHg}$. The patient was also directed for ECHO cardiograph in which the following were observed, M-moderate measurements- the left ventricular diastolic was $4.5 \mathrm{cms}$ and systolic was $2.6 \mathrm{cms}$. The right ventricular diastolic was $2.9 \mathrm{cms}$, left atrium $2.7 \mathrm{cms}$ and TAPSE was 2 . Further $2 \mathrm{D}$ study and Doppler study was also carried out: (Figure 1)

The patient was also found having hypothyroidism (TSH-0.23) along with Dyslipidemia (low HDL) and VIT D Deficiency (plasma Vitamin $\mathrm{D}$ 12.6). While the medication was going on for the above-mentioned diseases just a couple of weeks later the patient again complained of having right Hemiparesis along with radicular pain in the right lower limb (LL). One month back afternoon she had a sudden onset of right lower limb weakness which made it difficult to walk. Also, low backache since a month radiating till ankle and increased with walking. After the physical tests according to the complaints made by the patient, it was found that she was having an extruded disc at L4-L5. CT done in May 2019 showed a left basal ganglionic infarct.

\section{DIAGNOSIS}

The patient was referred for spine surgery. Other important impressions made were as following, MILD CAD NIL CARDIAC COMPLAINTS NORMAL LV, CONCENTRIC LVH ECG-NSR, NON-DM/The blood pressure was noted to be 132/80 mmHg. HYPOTHYROID/H/ OCVA+NO ADDICTION/POSTMENOPAUSAL. ${ }^{12,13}$ 

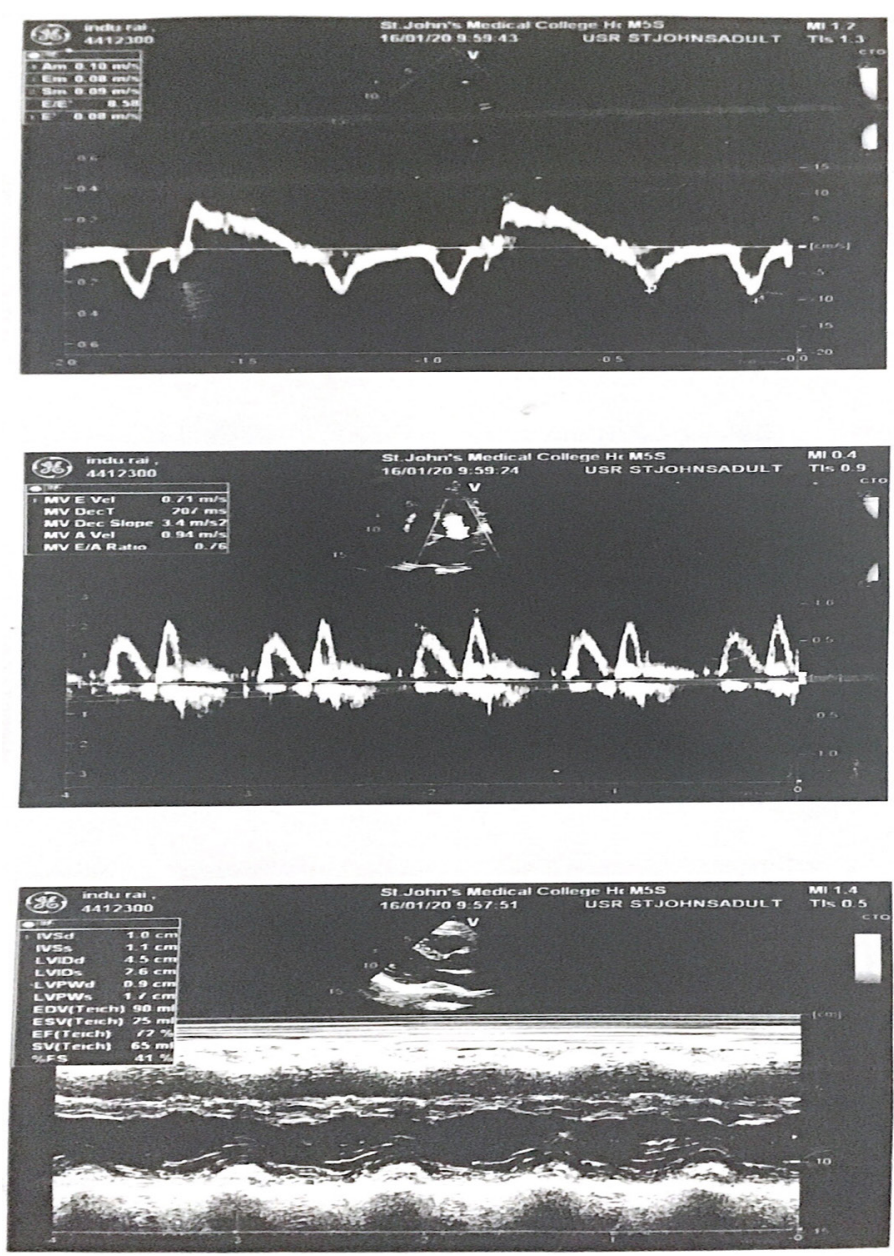

Figure 1: Pictures showing the $\mathrm{ECHO}$ cardiograph reports of the patient.

1. LMCA: Normal.

2. LAD: Mid Mild stenosis $25-49 \%$. Proximal D1 focal severe stenosis (70-99\%)

3. LCX: Co-dominant. Normal. 4. RCA: Co-dominant. Proximal RCA mild stenosis (25-49\%).

\section{MANAGEMENT PLAN}

The patient was prescribed with nutrition -Diet chart based on the disease state as the following were shown in (Figure 2).

Along with the diet plan, the patient has also prescribed with some medicines like Tab Telmisartan $40 \mathrm{mg}$, Metoprolol 50mg(1-0-0), Tab Amlodipine $5 \mathrm{mg}(0-0-1)$, Tab Atorvastatin $10 \mathrm{mg}+$ clopidogrel $75 \mathrm{mg}$ + Aspirin 75mg (0-0-2) with the instruction to check the BP (blood pressure) once every month. The patient should maintain $\mathrm{BP}<130 / 80$ $\mathrm{mmHg}$ and restrict salt in the diet. The patient should also avoid any canned or fast food. Hence patient was given approval for the surgery/ procedure with due risk. ${ }^{14-16}$

\section{DISCUSSION}

A 63-year-old female known (May 2019), hypothyroidism, old cerebrovascular accident (CVA) left capsuloganglionic (May 2019) came with the above-mentioned complaints. MRI brain showed encephalomalacia changes in left thalanocapsular regions. MRI LS spine showed IVDP with severe narrowing at L4 L5. As a part of stroke work up $2 \mathrm{D}$ echo was done normally. CTA WAS planned and to be done on

\begin{tabular}{|c|c|c|}
\hline FOODS & RESTRICT & ALLOWED \\
\hline Vegetables & $\begin{array}{l}\text { Potato, yam, tapioca, sweet potato } \\
\text { *Cabbage, cauliflower, radish, soybean, turnip, } \\
\text { spinach, Broccoli }\end{array}$ & All other vegetables. \\
\hline Fruits & $\begin{array}{l}\text { Banana, seethphal, sapota, avocado } \\
\text { *strawberries }\end{array}$ & All other fruits. \\
\hline Milk & $\begin{array}{l}\text { Cheese, Paneer, butter, condensed milk, khoa, } \\
\text { cream. }\end{array}$ & $\begin{array}{l}\text { Milk, buttermilk, curds, skim milk powder in } \\
\text { moderation. }\end{array}$ \\
\hline Meat & $\begin{array}{l}\text { Kidney, liver, brain portion of meat, mutton, } \\
\text { pork, beef, egg yolk, sausages, ham etc. }\end{array}$ & Chicken, fish, egg white in moderation. \\
\hline Fats & $\begin{array}{l}\text { Butter, ghee, margarine, coconut oil, vanaspathi, } \\
\text { dalda. }\end{array}$ & $\begin{array}{l}\text { Safflower oil, sunflower oil, groundnut oil in } \\
\text { moderation. } \\
{[1 / 2 \text { lit/ Person/ month] }}\end{array}$ \\
\hline Miscellaneous & $\begin{array}{l}\text { Sugar, sweets, jaggery, honey, chocolates, ice } \\
\text { cream pepsi, soda, coca-cola. }\end{array}$ & Tea, coffee in moderation. \\
\hline Instant food & $\begin{array}{l}\text { Bournvita, horlicks, soups, pickles, sauces, } \\
\text { papads. }\end{array}$ & \\
\hline Bakery food & Bread, buns, puffs, cakes, biscuits. & \\
\hline Fried foods & $\begin{array}{l}\text { Chips, mixtures, vada, bonda, murukku, baiji, } \\
\text { fried meats. }\end{array}$ & \\
\hline
\end{tabular}

Advice:

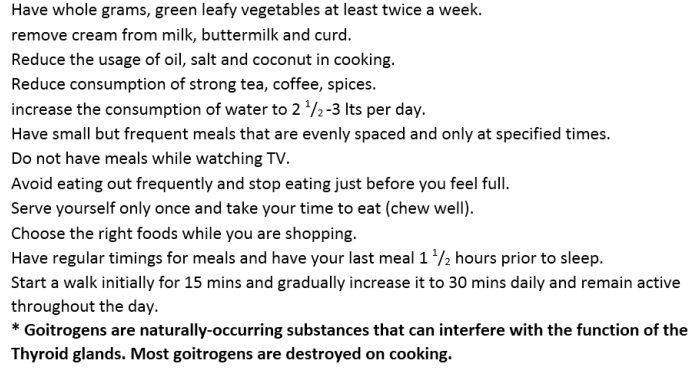

Figure 2: Diet chart of the patient

OPD basis. Neurosurgery opinion was taken and they have advised $4^{\text {th }}$ level stabilization Dexa Scan. TSH was 0.23 and hence thyronorm dose was reduced to $62.5 \mathrm{mcg}$. As the surgery was planned tab aspirin $(75 \mathrm{mg})$ + clopidogrel (75mg) was changed to ecospirin and the patient was advised to follow up in neurosurgery after a week. ${ }^{17-19}$

\section{CONCLUSION}

Lumbar spinal stenosis is a crucial cause of painful and immobilizing radiculitis that has been treated habitually with the rising population, although spinal imaging inspections are available. Herein, we documented the case of a 63-year-old female with Lumbar spinal stenosis along with hypertension and hypothyroidism. Therefore it is highly recommended for the patients with LSS to go through initial proper medication than to finally be undergoing surgical treatment. ${ }^{20-22}$

\section{ACKNOWLEDGEMENT}

We take this opportunity to express our gratitude and respect thanks to our beloved Dr. Suresh Nagpal, Chairman Krupanidhi Group of Institutions Bangalore. Dr. Amitkumar Das Principal, Krupanidhi College of Pharmacy, Bangalore and the faculty members who provided us the support and assistance to this research work.

\section{CONFLICT OF INTEREST}

The authors declare no conflict of interest.

\section{ABBREVIATIONS}

LSS: Lumbar spinal stenosis; HDL: high density lipoprotein; LL: Lower Limb; CT: Computed Tomography; CAD: Coronary Artery Disease; LV: 
Left Ventricle; LVH: Left Ventricular Hypertrophy; ECG: Echo Cardio Gram; NSR: Normal Sinus Rhythm; NON-DM: Non Insulin Dependent Diabetes Mellitus; LMCA: Left Main Coronary Artery; LAD: Left Anterior Descending; LCX: Left Circulflex; MRI: Magnetic Resonance Imaging; BP: Blood Pressure; CVA: Cerebrovascular accident; OPD: Out patient Department; CTA: Computed Tomography Angiography.

\section{REFERENCES}

1. Hinck VC, Gordy PD, Storing HE. Development stenosis of the cervical spinal canal: Radiological Considerations. Neurology. 1964;14(9):864-8.

2. Sharma M, Langrana NA, Rodriguez J. Role of ligaments and facets in lumbar spinal instability. Spine. 1995;20(8):887-90.

3. Weinstein PR. The application of anatomy and pathophysiology in the management of lumbar spine disease. Clin Neuro-Surg. 1980;27(Suppl 1):51740.

4. Papp T, Porter RW, Craig CE, Aspden RM, Campbell DM. Significant antenata factors in the development of lumbar spinal stenosis. Spine. 1997;22(16):180510.

5. Moreland LW, Lopez MA, Alarcon GS. Spinal stenosis: a comprehensive review of the literature. Semin Arthritis Rheum. 1989;19(2):127-49.

6. Hall S, Bartleson JD, Onofrio BM, JrBaker HI, Okazaki H, O'Duffy JD. Lumbar spinal stenosis: clinical features, diagnostic procedures and results of surgical treatment in 68 patients. Ann Intern Med. 1985;103(2):271-5.

7. Dyck P, Pheasant HC, Doyle JB, et al. Intermittent cauda equina compression syndrome: its recognition and treatment. Spine. 1977;2(1):75-81.

8. Simotas AC. Non operative treatment for lumbar spinal stenosis. Clin Orthop. $2001 ; 384: 153-61$.
9. Turner JA, Ersek M, Herron L, Deyo R. Surgery for lumbar spinal stenosis: Attempted meta-analysis of the literature. Spine. 1992;17(1):1-8.

10. Grabias S. The treatment of spinal stenosis. J Bone Joint Surg Am. 1980;62:30813

11. Pinsky Le, Wipro JE, Ramsey SD. Evidence-Based Clinical Practice: Concepts and approaches. Boston: Butterwortg. 2000.

12. Eisenstein S. Lumbar vertebral canal morphometry for computerised tomography in spinal stenosis. Spine. 1983;8(2):187-97.

13. Verbiest $H$. A radicular syndrome from developmental narrowing of lumbar vertebral canal. J Bone Joint Surg Am. 1954;36(2):230-7.

14. Porter RW. Central spinal stenosis: Classification and pathogenesis. Acts Orthop Scand. 1993;64(suppl 251):64-6.

15. Rydevik B. Neurophysiology of cauda equina compression. Acta Orthop Scand. 1993;64(suppl 251):52-5.

16. Teng P, Papatheodorou C. Lumbar spondylosis with compression of cauda equina. Arch Neurol. 1963;8(2):221-8.

17. Knutsson B, Sanden B, Sjoden G, Jarvholm B, Michaelsson K. Body mass index and risk for clinical lumbar spinal stenosis: A cohort study. Spine. 2015:40(18):1451-6

18. Gene S, Atlas SJ. Lumbar spinal stenosis. Best Pract Res Clin Rheumatol 2010;24(2):253-65.

19. Turner J, Ersek M, Herron L, et al. Patient outcomes after lumbar spinal fusions JAMA. 1992;268(7):907-11.

20. Spinavak J. Degenerative lumbar spinal stenosis. J Bone Joint Surg 1998;80(7):1053-66

21. Blau JN, Logue V. Intermittent Claudication of the cauda equina. Lancet. 1961;1:1081-6.

22. Hayloft A. Factors in the development of spinal stenosis syndrome. J Bone Joint Surg Br. 1978;61(3):319-28.

Article History: Submission Date: 14-05-2020; Revised Date : 09-06-2020; Acceptance Date : 16-07-2020

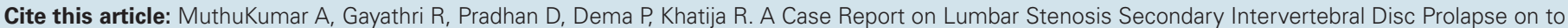
IVDP L4/L5 Associated with Hypertension and Hypothyroidism in Female. J Young Pharm. 2020;12(3):288-90. 